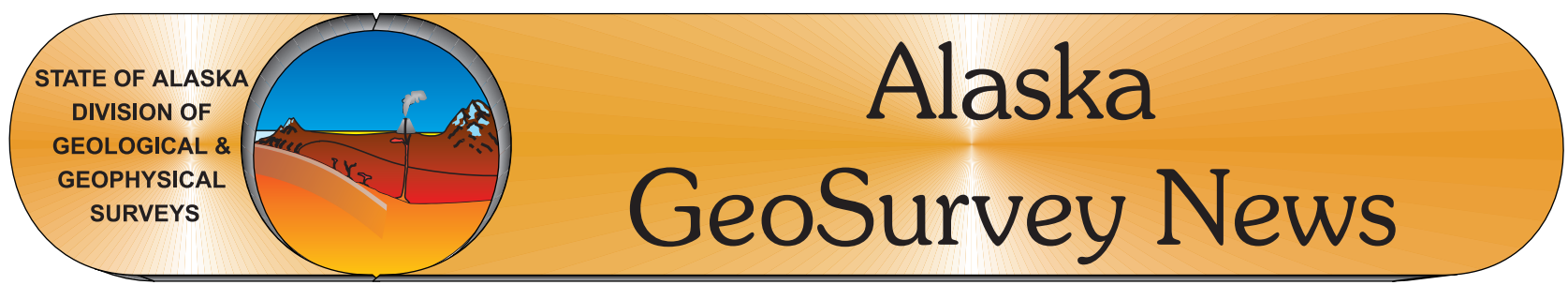

http://www.dggs.dnr.state.ak.us

Vol. 6, No. 1, March 2004

Should read Vol. 7, not Vol. 6

\title{
THE GEOLOGIC DATABASE OF INFORMATION ON VOLCANOES IN ALASKA (GEODIVA): A COMPREHENSIVE AND AUTHORITATIVE SOURCE FOR VOLCANIC INFORMATION
}

\author{
by Cheryl Cameron
}

Alaska has more than its share of volcanoes. In fact, Alaska contains almost 80 percent of all active volcanoes in the U.S., and 8 percent of all active above water volcanoes on earth. Since 1760, there have been more than 265 eruptions in Alaska (Miller and others, 1998). This is nearly one eruption per year.

There are 42 historically active volcanoes in Alaska, and more than 40 other volcanoes that have erupted within the last 10,000 years (Miller and others, 1998). Although many of these volcanoes are located in the sparsely populated Aleutian Islands, volcanic ash spewed into the sky poses a deadly hazard to the numerous international air routes that parallel the Aleutian volcanic arc. Ten thousand people fly every day in aircraft that follow these air routes, and more than 80,000 aircraft cross the Aleutian Arc per year. Additionally, four historically active volcanoes are close to Anchorage and Cook Inlet: Augustine, Iliamna, Redoubt, and Spurr.

In May 2002 the Alaska Volcano Observatory (AVO) formally began creating a database system for information on Pleistocene and younger (last 2 million years) volcanoes in Alaska. The new database system will assist the AVO with crisis response and volcano investigations, as well as inform the general public about Alaska's volcanoes. It will also provide an updateable back end to AVO's existing public Web site (http:/ /www.avo.alaska.edu) and replace the existing Atlas section with more detailed information. The goal is to become the most complete "one stop shop" for Alaska volcano information.

AVO is a joint program of the United States Geological Survey (USGS), the Geophysical Institute of the University of Alaska Fairbanks (UAF/GI), and the State of Alaska Division of Geological \& Geophysical Surveys (DGGS). Two DGGS employees have been hired to work on the database. I began work in May 2002 on creating the database, and Seth Snedigar was hired in January 2004 as AVO's Webmaster. Seth will also create an interface between the database and the Web site.

\section{THE PROCESS OF CREATING GEODIVA}

During the fall of 2002, another DGGS geologist, Janet Schaefer, and I conducted database needs-assessment interviews with $\mathrm{AVO}$ geoscientists. Information gathered from these interviews was used to determine what types of information GeoDIVA should store, and what details were necessary for each different type of information. Also collected during the interviews were sample questions that people would want to ask GeoDIVA - these questions demonstrated not only what information people were most interested in, but also how they wanted to be able to access it. GeoDIVA is being structured so that the most commonly asked questions will be easy to answer. Examples of these questions include:

When did volcano $\mathrm{X}$ last erupt?

What eruption styles are known for volcano X? 
- Has volcano X ever caused an air traffic control problem?

- What references discuss a certain eruption of volcano $\mathrm{X}$ ?

The highest priorities for the database are:

- A complete bibliography of documents about Alaska volcanoes;

- Basic volcano information, such as location, elevation, and a short description;

- Detailed eruption history information with scanned documents of historical eruption eyewitness accounts;

- An image library including historic and recent slides, photographs, and airphotos;

- Geochemical sample data; and

- Georeferenced basemap data.

\section{WHO WILL USE GEODIVA?}

GeoDIVA will serve two main user groups: Geoscientists at AVO and members of the general public who are interested in volcanoes.

AVO geoscientists will use GeoDIVA as a place to begin gathering information as they study and complete geologic and hazard assessments for Alaska volcanoes, and as an important source for instant information in the event of a volcanic crisis. For example, GeoDIVA will tell them which geologic maps are available for a volcano, how many chemical analyses have been obtained from rocks from that volcano, what image resources are available for a volcano, and which published documents contain information about the volcano. GeoDIVA will also quickly inform them about any eruptions from a volcano that have negatively impacted people, infrastructure, or aviation.

AVO's Web site is accessed more than 3,000 times per day by students, teachers, geoscientists from inside and outside Alaska, and other folks just curious about volcanoes. When GeoDIVA becomes part of the Web site, not only will there be more information available to them, but it will be easier to find more information in answer to a specific question. It will be easier for an eighth-grader, for example, to gather references for a report on aviation and ash hazards, and easier for someone to determine which volcano erupted while he was living in Anchorage.

\section{What PROGRESS HAS BEEN MADE?}

This is a large project, and will take some time to complete. Each section of the database is being completed separately and sections will be linked together as they are finished. Substantial progress has already been made. The structure is complete and data entered for bibliographic references-more than 3,370 references and counting. This information is available as a fully searchable Microsoft Access database from DGGS as MP131, and is also downloadable from AVO's Web site.

The eruption history database structure is complete, and data are 95 percent complete for basic volcano information. We are now compiling and entering data for the eruption histories portion of the database. Many sources of information must be painstakingly gathered, because the information does not already exist in any one location. Finding a particular document often means calling several out-of-state libraries and, once the document is located, getting special permission to borrow a "reference only" book. After all available data for a particular volcano has been collected, read, and analyzed, information must be filtered and entered into the database. Data must be entered carefully and consistently to maintain database integrity and to permit comparison between database entries.

During FY04, the database will be migrated from Microsoft Access to a larger database management system, and we will begin making some GeoDIVA information dynamically available on the Web.

\section{References Cited}

Cameron, C.E., Triplehorn, J.H., Robar, C.L., 2003, Bibliography of information on Alaska volcanoes: Alaska Division of Geological \& Geophysical Surveys Miscellaneous Publication 131, 1 CD-ROM.

Miller, T.P., McGimsey, R.G., Richter, D.H., Riehle, J.R., Nye, C.J., Yount, M.E., and Dumoulin, J.A., 1998, Catalog of the historically active volcanoes of Alaska: U.S. Geological Survey Open-File Report OF 98-0582, 104 p.

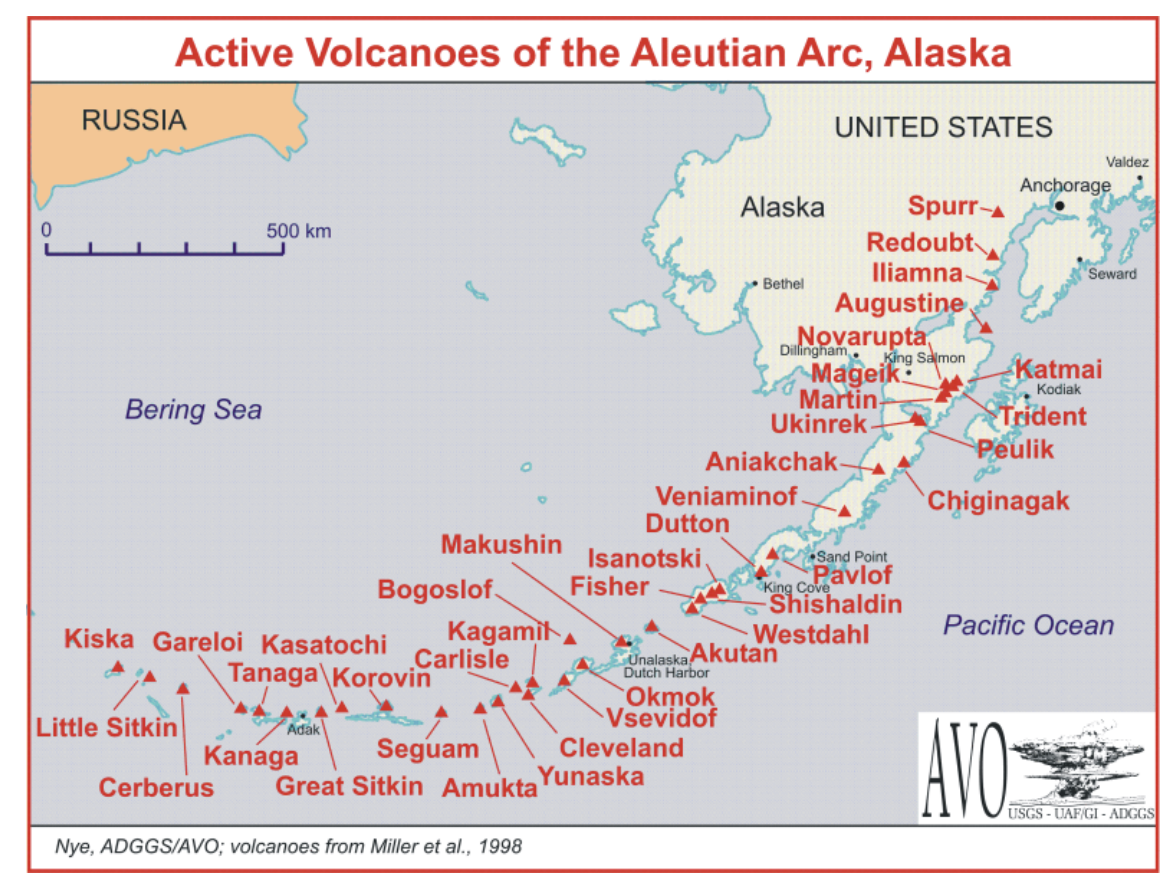




\section{STATE OF ALASKA \\ DEPARTMENT OF NATURAL RESOURCES \\ DIVISION OF GEOLOGICAL \& GEOPHYSICAL SURVEYS}

Mail order to:

Division of Geological \& Geophysical Surveys

E-maildggspubs@dnr.state.ak.us

Attn: Geologic Communications Section

http://wwwdggs.dnr.state.ak.us

Publication Sales

Phone: (907) 451-5020

3354 College Rd.

Fax: (907) 451-5050

Fairbanks, Alaska 99709-3707

\begin{tabular}{|c|c|c|c|c|c|}
\hline REPORT NO. & TitLe & QuANTITY & $\begin{array}{r}\text { UNIT } \\
\text { PRICE }\end{array}$ & Postage & Total \\
\hline & & & & & \\
\hline & & & & & \\
\hline & & & & & \\
\hline & & & & & \\
\hline & & & & & \\
\hline & & & & & \\
\hline & & & & & \\
\hline & & \multicolumn{3}{|c|}{ Total amount due } & \\
\hline
\end{tabular}

Domestic postage $\$ 1.00$ per copy of each report ordered

Canada and Mexico, $\$ 1.50$ per copy of each report

ordered

All other international, $\$ 2.50$ surface, $\$ 5.00$ air mail per

copy of each report ordered

\section{Ship publication(s) to:}

Name

Organization

Address

City, State

Zip

Payment must accompany your order. Make check or money order payable to STATE OF ALASKA.

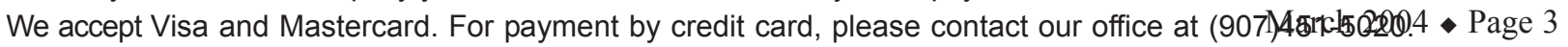




\section{NEW PUBLICATIONS}

\section{GEOPHYSICAL MAPS \& REPORTS}

GPR 2003_5. Plot files of the airborne geophysical survey data of the southern Delta River area, east-central Alaska, by L.E. Burns, U.S. Bureau of Land Management, Fugro Airborne Surveys, and Stevens Exploration Management Corp., 2003, 1 CD-ROM. Contains the 19 maps listed below as GPR2003_5_xy in both HPGL/2 format and postscript printer format. The HPGL2 plot files (prn printer file format) were made with an HP Designjet $2500 \mathrm{HPGL} / 2$ printer driver v4.61 and must be plotted on an HP Designjet 2500. The postscript plot files (ps printer file format) were made with an Hewlett Packard Designjet 2500 Postscript 3 printer driver v5.0 and should plot on all Hewlett Packard plotters that can interpret postscript 3 files. $\$ 10$.

GPR 2003_5_1a. Total magnetic field of the southern Delta River area, east-central Alaska, by L.E. Burns, U.S. Bureau of Land Management, Fugro Airborne Surveys, and Stevens Exploration Management Corp., 2003, 2 sheets, scale 1:63,360. Topography included. Full-color plot from electronic file, 600 dpi. \$26.

GPR 2003_5_1b. Total magnetic field of the southern Delta River area, east-central Alaska, by L.E. Burns, U.S. Bureau of Land Management, Fugro Airborne Surveys, and Stevens Exploration Management Corp., 2003, 2 sheets, scale 1:63,360. Magnetic contours and section lines included. Full-color plot from electronic file, 600 dpi. \$26.

GPR 2003_5_1c. Color shadow magnetic map of the southern Delta River area, east-central Alaska, by L.E. Burns, U.S. Bureau of Land Management, Fugro Airborne Surveys, and Stevens Exploration Management Corp., 2003, 2 sheets, scale 1:63,360. Full-color plot from electronic file, 600 dpi. \$26.

GPR 2003_5_1d. Total magnetic field and electromagnetic anomalies of the southern Delta River area, east-central Alaska, by L.E. Burns, U.S. Bureau of Land Management, Fugro Airborne Surveys, and Stevens Exploration Management Corp., 2003, 2 sheets, scale 1:63,360. Magnetic contours, simplified electromagnetic anomalies, and section lines included. Black and white plot from electronic file, 600 dpi. $\$ 8$.

GPR 2003_5_2a. Total magnetic field and detailed electromagnetic anomalies of the southern Delta River area, east-central Alaska, by L.E. Burns, U.S. Bureau of Land Management, Fugro Airborne Surveys, and Stevens Exploration Management Corp., 2003, 1 sheet, scale 1:31,680 (parts of Mt. Hayes A-5, A-6, B-5, and B-6 quadrangles). Magnetic contours, detailed electromagnetic anomalies, and topography included. Black and white plot from electronic file, 600 dpi. \$3.

GPR 2003_5_2b. Total magnetic field and detailed electromagnetic anomalies of the southern Delta River area, east-central Alaska, by L.E. Burns, U.S. Bureau of Land Management, Fugro Airborne Surveys, and Stevens Exploration Management Corp., 2003, 1 sheet, scale 1:31,680 (parts of Mt. Hayes A-4, A-5, B-4, and B-5 quadrangles). Magnetic contours, detailed electromagnetic anomalies, and topography included. Black and white plot from electronic file, 600 dpi. $\$ 3$.

GPR 2003_5_2c. Total magnetic field and detailed electromagnetic anomalies of the southern Delta River area, east-central Alaska, by L.E. Burns, U.S. Bureau of Land Management, Fugro Airborne Surveys, and Stevens Exploration Management Corp., 2003, 1 sheet, scale 1:31,680 (parts of Mt. Hayes A-3, A-4, B-3, and B-4 quadrangles). Magnetic contours, detailed electromagnetic anomalies, and topography included. Black and white plot from electronic file, 600 dpi. $\$ 5$.

GPR 2003_5_2d. Total magnetic field and detailed electromagnetic anomalies of the southern Delta River area, east-central Alaska, by L.E. Burns, U.S. Bureau of Land Management, Fugro Airborne Sur- veys, and Stevens Exploration Management Corp., 2003, 1 sheet, scale 1:31,680 (parts of Mt. Hayes A-5 Quadrangle). Magnetic contours, detailed electromagnetic anomalies, and topography included. Black and white plot from electronic file, 600 dpi. $\$ 3$.

GPR 2003_5_2e. Total magnetic field and detailed electromagnetic anomalies of the southern Delta River area, east-central Alaska, by L.E. Burns, U.S. Bureau of Land Management, Fugro Airborne Surveys, and Stevens Exploration Management Corp., 2003, 1 sheet, scale 1:31,680 (parts of Mt. Hayes A-4 and A-5 quadrangles). Magnetic contours, detailed electromagnetic anomalies, and topography included. Black and white plot from electronic file, 600 dpi. \$3.

GPR 2003_5_2f. Total magnetic field and detailed electromagnetic anomalies of the southern Delta River area, east-central Alaska, by L.E. Burns, U.S. Bureau of Land Management, Fugro Airborne Surveys, and Stevens Exploration Management Corp., 2003, 1 sheet, scale 1:31,680 (parts of Mt. Hayes A-4 Quadrangle). Magnetic contours, detailed electromagnetic anomalies, and topography included. Black and white plot from electronic file, 600 dpi. \$3.

GPR 2003_5_2g. Total magnetic field and detailed electromagnetic anomalies of the southern Delta River area, east-central Alaska, by L.E. Burns, U.S. Bureau of Land Management, Fugro Airborne Surveys, and Stevens Exploration Management Corp., 2003, 1 sheet, scale 1:31,680 (parts of Mt. Hayes A-3 and A-4 quadrangles). Magnetic contours, detailed electromagnetic anomalies, and topography included. Black and white plot from electronic file, 600 dpi. \$3.

GPR 2003_5_3a. $7200 \mathrm{~Hz}$ coplanar resistivity of the southern Delta River area, east-central Alaska, by L.E. Burns, U.S. Bureau of Land Management, Fugro Airborne Surveys, and Stevens Exploration Management Corp., 2003, 2 sheets, scale 1:63,360. Topography included. Full-color plot from electronic file, 600 dpi. \$26.

GPR 2003_5_3b. $7200 \mathrm{~Hz}$ coplanar resistivity of the southern Delta River area, east-central Alaska, by L.E. Burns, U.S. Bureau of Land Management, Fugro Airborne Surveys, and Stevens Exploration Management Corp., 2003, 2 sheets, scale 1:63,360. Resistivity contours and section lines included. Full-color plot from electronic file, 600 dpi. \$26.

GPR 2003_5_3c. $7200 \mathrm{~Hz}$ coplanar resistivity of the southern Delta River area, east-central Alaska, by L.E. Burns, U.S. Bureau of Land Management, Fugro Airborne Surveys, and Stevens Exploration Management Corp., 2003, 2 sheets, scale 1:63,360. Resistivity contours and section lines included. Black and white plot from electronic file, 600 dpi. $\$ 8$.

GPR 2003_5_4a.900 Hz coplanar resistivity of the southern Delta River area, east-central Alaska, by L.E. Burns, U.S. Bureau of Land Management, Fugro Airborne Surveys, and Stevens Exploration Management Corp., 2003, 2 sheets, scale 1:63,360. Topography included. Full-color plot from electronic file, 600 dpi. \$26.

GPR 2003_5_4b.900 Hz coplanar resistivity of the southern Delta River area, east-central Alaska, by L.E. Burns, U.S. Bureau of Land Management, Fugro Airborne Surveys, and Stevens Exploration Management Corp., 2003, 2 sheets, scale 1:63,360. Resistivity contours and section lines included. Full-color plot from electronic file, $600 \mathrm{dpi}$. $\$ 26$.

GPR 2003_5_4c. $900 \mathrm{~Hz}$ coplanar resistivity of the southern Delta River area, east-central Alaska, by L.E. Burns, U.S. Bureau of Land Management, Fugro Airborne Surveys, and Stevens Exploration Management Corp., 2003, 2 sheets, scale 1:63,360. Resistivity contours and section lines included. Black and white plot from electronic file, 600 dpi. $\$ 8$.

GPR 2003_5_5a. Flight lines of the southern Delta River area, eastcentral Alaska, by L.E. Burns, U.S. Bureau of Land Management, Fugro Airborne Surveys, and Stevens Exploration Management Corp., 2003, 2 sheets, scale 1:63,360. Topography included. Black and white plot 
from electronic file, 600 dpi. $\$ 8$.

GPR2003_5_6a. Digital elevation model of the the southern Delta River area, east-central Alaska, by L.E. Burns, U.S. Bureau of Land Management, Fugro Airborne Surveys, and Stevens Exploration Management Corp., 2003, 2 sheets, scale 1:63,360. Elevation contours and section lines included. Produced from survey altimetry. Full-color plot from electronic file, 600 dpi. \$26.

GPR 2003_6. Line, grid, and vector data of airborne geophysical survey data for the southern Delta River area, east-central Alaska, by L.E. Burns, U.S. Bureau of Land Management, Fugro Airborne Surveys, and Stevens Exploration Management Corp., 2003, 1 CD-ROM. Line data in ASCII format; gridded data in Geosoft format; vector files in Autocad 14 dxf files. \$20.

GPR 2003_7. Project report of the airborne geophysical survey of the southern Delta Rvier area, east-central Alaska, by Ruth Pritchard, Fugro Airborne Surveys, 2003, 252 p., 2 sheets, scale 1:63,360. \$30.

GPR 2003_8. Portfolio of aeromagnetic and resistivity maps of the southern Delta River area, east-central Alaska, by L.E. Burns and K.H. Clautice, 2003, 15 p. Includes color and shadow maps. Maps fit 81/2" x 11" sheet. $\$ 6$.

GPR 2003 9. Plot files of the airborne geophysical survey data of the Sleetmute area, southwestern Alaska, by L.E. Burns, U.S. Bureau of Land Management, Fugro Airborne Surveys, and Stevens Exploration Management Corp., 2003, 1 CD-ROM. Contains the 18 maps listed below as GPR2003_9_xy in both HPGL/2 format and postscript printer format. The HPGL2 plot files (prn printer file format) were made with an HP Designjet $2500 \mathrm{HPGL} / 2$ printer driver v4.61 and must be plotted on an HP Designjet 2500. The postscript plot files (ps printer file format) were made with an Hewlett Packard Designjet 2500 Postscript 3 printer driver v5.0 and should plot on all Hewlett Packard plotters that can interpret postscript 3 files. $\$ 10$.

GPR 2003_9_1a. Total magnetic field of the Sleetmute area, southwestern Alaska, by L.E. Burns, U.S. Bureau of Land Management, Fugro Airborne Surveys, and Stevens Exploration Management Corp., 2003, 2 sheets, scale 1:63,360. Topography included. Full-color plot from electronic file, 600 dpi. \$26.

GPR 2003_9_1b. Total magnetic field of the Sleetmute area, southwestern Alaska, by L.E. Burns, U.S. Bureau of Land Management, Fugro Airborne Surveys, and Stevens Exploration Management Corp., 2003, 2 sheets, scale 1:63,360. Magnetic contours and section lines included. Full-color plot from electronic file, 600 dpi. \$26.

GPR 2003_9_1c. Color shadow magnetic map of the Sleetmute area, southwestern Alaska, by L.E. Burns, U.S. Bureau of Land Management, Fugro Airborne Surveys, and Stevens Exploration Management Corp., 2003, 2 sheets, scale 1:63,360. Full-color plot from electronic file, 600 dpi. $\$ 26$.

GPR 2003_9_1d. Total magnetic field and electromagnetic anomalies of the Sleetmute area, southwestern Alaska, by L.E. Burns, U.S. Bureau of Land Management, Fugro Airborne Surveys, and Stevens Exploration Management Corp., 2003, 2 sheets, scale 1:63,360. Magnetic contours, simplified electromagnetic anomalies, and section lines included. Black and white plot from electronic file, 600 dpi. $\$ 8$.

GPR 2003_9_2a. Total magnetic field and detailed electromagnetic anomalies of the Sleetmute area, southwestern Alaska, by L.E. Burns, U.S. Bureau of Land Management, Fugro Airborne Surveys, and Stevens Exploration Management Corp., 2003, 1 sheet, scale 1:31,680 (part of Iditarod A-4 Quadrangle). Magnetic contours, detailed electromagnetic anomalies, and topography included. Black and white plot from electronic file, 600 dpi. $\$ 4$.

GPR 2003_9_2b. Total magnetic field and detailed electromagnetic anomalies of the Sleetmute area, southwestern Alaska, by L.E. Burns, U.S. Bureau of Land Management, Fugro Airborne Surveys, and Stevens Exploration Management Corp., 2003, 1 sheet, scale 1:31,680 (parts of Sleetmute D-5 and D-6 quadrangles). Magnetic contours, de- tailed electromagnetic anomalies, and topography included. Black and white plot from electronic file, 600 dpi. $\$ 4$.

GPR 2003_9_2c. Total magnetic field and detailed electromagnetic anomalies of the Sleetmute area, southwestern Alaska, by L.E. Burns, U.S. Bureau of Land Management, Fugro Airborne Surveys, and Stevens Exploration Management Corp., 2003, 1 sheet, scale 1:31,680 (parts of Sleetmute D-4 and D-5 quadrangles). Magnetic contours, detailed electromagnetic anomalies, and topography included. Black and white plot from electronic file, 600 dpi. $\$ 4$.

GPR 2003_9_2d. Total magnetic field and detailed electromagnetic anomalies of the Sleetmute area, southwestern Alaska, by L.E. Burns, U.S. Bureau of Land Management, Fugro Airborne Surveys, and Stevens Exploration Management Corp., 2003, 1 sheet, scale 1:31,680 (parts of Sleetmute C-5, C-6, D-5 and D-6 quadrangles). Magnetic contours, detailed electromagnetic anomalies, and topography included. Black and white plot from electronic file, 600 dpi. $\$ 4$.

GPR 2003_9_2e. Total magnetic field and detailed electromagnetic anomalies of the Sleetmute area, southwestern Alaska, by L.E. Burns, U.S. Bureau of Land Management, Fugro Airborne Surveys, and Stevens Exploration Management Corp., 2003, 1 sheet, scale 1:31,680 (parts of Sleetmute C-4, C-5, D-4 and D-5 quadrangles). Magnetic contours, detailed electromagnetic anomalies, and topography included. Black and white plot from electronic file, 600 dpi. $\$ 4$.

GPR 2003_9_2f. Total magnetic field and detailed electromagnetic anomalies of the Sleetmute area, southwestern Alaska, by L.E. Burns, U.S. Bureau of Land Management, Fugro Airborne Surveys, and Stevens Exploration Management Corp., 2003, 1 sheet, scale 1:31,680 (parts of Sleetmute C-4 and C-5 quadrangles). Magnetic contours, detailed electromagnetic anomalies, and topography included. Black and white plot from electronic file, $600 \mathrm{dpi}$. \$4.

GPR 2003_9_3a. $7200 \mathrm{~Hz}$ coplanar resistivity of the Sleetmute area, southwestern Alaska, by L.E. Burns, U.S. Bureau of Land Management, Fugro Airborne Surveys, and Stevens Exploration Management Corp., 2003, 2 sheets, scale 1:63,360. Topography included. Fullcolor plot from electronic file, 600 dpi. \$26.

GPR 2003_9_3b. $7200 \mathrm{~Hz}$ coplanar resistivity of the Sleetmute area, southwestern Alaska, by L.E. Burns, U.S. Bureau of Land Management, Fugro Airborne Surveys, and Stevens Exploration Management Corp., 2003, 2 sheets, scale 1:63,360. Resistivity contours and section lines included. Full-color plot from electronic file, 600 dpi. \$26.

GPR 2003_9_3c. $7200 \mathrm{~Hz}$ coplanar resistivity of the Sleetmute area, southwestern Alaska, by L.E. Burns, U.S. Bureau of Land Management, Fugro Airborne Surveys, and Stevens Exploration Management Corp., 2003, 2 sheets, scale 1:63,360. Resistivity contours and section lines included. Black and white plot from electronic file, 600 dpi. $\$ 8$.

GPR 2003_9_4a. $900 \mathrm{~Hz}$ coplanar resistivity of the Sleetmute area, southwestern Alaska, by L.E. Burns, U.S. Bureau of Land Management, Fugro Airborne Surveys, and Stevens Exploration Management Corp., 2003, 2 sheets, scale 1:63,360. Topography included. Fullcolor plot from electronic file, 600 dpi. \$26.

GPR 2003_9_4b. $900 \mathrm{~Hz}$ coplanar resistivity of the Sleetmute area, southwestern Alaska, by L.E. Burns, U.S. Bureau of Land Management, Fugro Airborne Surveys, and Stevens Exploration Management Corp., 2003, 2 sheets, scale 1:63,360. Resistivity contours and section lines included. Full-color plot from electronic file, 600 dpi. \$26.

GPR 2003_9_4c. $900 \mathrm{~Hz}$ coplanar resistivity of the Sleetmute area, southwestern Alaska, by L.E. Burns, U.S. Bureau of Land Management, Fugro Airborne Surveys, and Stevens Exploration Management Corp., 2003, 2 sheets, scale 1:63,360. Resistivity contours and section lines included. Black and white plot from electronic file, 600 dpi. $\$ 8$.

GPR 2003_9_5. Flight lines of the Sleetmute area, southwestern Alaska, by L.E. Burns, U.S. Bureau of Land Management, Fugro Airborne Surveys, and Stevens Exploration Management Corp., 2003, 2 sheets, scale 
1:63,360. Topography included. Black and white plot from electronic file, 600 dpi. $\$ 8$.

GPR 2003_10. Line, grid, and vector data of the airborne geophysical survey data of the Sleetmute area, southwestern Alaska, 1 CD-ROM set. Line data in ASCII format; gridded data in Geosoft and ER Mapper format; vector files in Autocad 13 dxf files. \$20.

GPR 2003_11. Project report of the airborne geophysical survey of the Sleetmute area, southwestern Alaska, by Ruth Pritchard, Fugro Airborne Surveys, 2003, 211, p., 2 sheets, scale 1:63,360. \$30.

GPR 2003_12. Portfolio of aeromagnetic and resistivity maps of the Sleetmute area, southwestern Alaska, Includes color and shadow maps. Maps fit 81/2" x 11" sheet. To be determined

\section{INFORMATION CIRCULARS}

IC 49. Alaska's mineral industry 2002: a summary, by D.J. Szumigala and R.C. Swainbank, 2003, 15 p. Free.

IC 50. Alaska's mineral industy 2003: a summary, by D.J. Szumigala and R.H. Harris, 2004, 12 p. Free.

\section{MISCELLANEOUS PUBLICATIONS}

MP 58. Survey of geology and geologic materials, and geologic hazards in proposed access corridors in the Chandalar Quadrangle, Alaska, by D.S.P. Stevens and R.L. Smith, 5 sheets, scale 1:250,000. $\$ 65$.

MP 59. Survey of geology and geologic materials, and geologic hazards in proposed access corridors in the Chandler Lake Quadrangle, Alaska, by D.S.P. Stevens and R.L. Smith, 5 sheets, scale $1: 250,000 . \$ 65$.

MP 61. Survey of geology and geologic materials, and geologic hazards in proposed access corridors in the Chignik Point Quadrangle, Alaska, by R.D. Reger, K.M. Campbell, D.S.P. Stevens, and R.L. Smith, 5 sheets, scale 1:250,000. $\$ 65$.

MP 66. Survey of geology and geologic materials, and geologic hazards in proposed access corridors in the Demarcation Point Quadrangle, Alaska, by D.S.P. Stevens and R.L. Smith, 5 sheets, scale 1:250,000. $\$ 65$.

MP 67. Survey of geology and geologic materials, and geologic hazards in proposed access corridors in the Dillingham Quadrangle, Alaska, by R.D. Reger, D.S.P. Stevens, and R.L. Smith, 4 sheets, scale $1: 250,000 . \$ 52$.

MP 68. Survey of geology and geologic materials, and geologic hazards in proposed access corridors in the Eagle Quadrangle, Alaska, by R.D. Reger, D.S.P. Stevens, and R.L. Smith, 5 sheets, scale 1:250,000. $\$ 65$.

MP 69. Survey of geology and geologic materials, and geologic hazards in proposed access corridors in the Fairbanks Quadrangle, Alaska, by R.D. Reger, D.S.P. Stevens, and R.L. Smith, 5 sheets, scale $1: 250,000 . \$ 65$.

MP 72. Survey of geology and geologic materials, and geologic hazards in proposed access corridors in the Healy Quadrangle, Alaska, by R.D. Reger, D.S.P. Stevens, and R.L. Smith, 5 sheets, scale $1: 250,000 . \$ 65$.

MP 73. Survey of geology and geologic materials, and geologic hazards in proposed access corridors in the Holy Cross Quadrangle, Alaska, by H.R. Livingston, G.R. Cruse, D.S.P. Stevens, and R.L. Smith, 5 sheets, scale 1:250,000. $\$ 65$.

MP 75. Survey of geology and geologic materials, and geologic hazards in proposed access corridors in the Hughes Quadrangle, Alaska, by R.D. Reger, D.S.P. Stevens, and R.L. Smith, 5 sheets, scale $1: 250,000$. $\$ 65$.

MP 76. Survey of geology and geologic materials, and geologic hazards in proposed access corridors in the Iditarod Quadrangle, Alaska, by R.D. Reger, G.R. Cruse, D.S.P. Stevens, and R.L. Smith 4 sheets, scale 1:250,000. $\$ 52$
MP 80. Survey of geology and geologic materials, and geologic hazards in proposed access corridors in the Kantishna River Quadrangle, Alaska, by D.S.P. Stevens and R.L. Smith, 5 sheets, scale $1: 250,000 . \$ 65$.

MP 81. Survey of geology and geologic materials, and geologic hazards in proposed access corridors in the Karluk Quadrangle, Alaska, by D.S.P. Stevens and R.L. Smith, 5 sheets, scale 1:250,000. $\$ 65$.

MP 82. Survey of geology and geologic materials, and geologic hazards in proposed access corridors in the Kateel River Quadrangle, Alaska, by R.D. Reger, G.R. Cruse, D.S.P. Stevens, and R.L. Smith, 5 sheets, scale 1:250,000. \$65.

MP 86. Survey of geology and geologic materials, and geologic hazards in proposed access corridors in the Livengood Quadrangle, Alaska, by R.D. Reger, D.S.P. Stevens, and R.L. Smith, 5 sheets, scale $1: 250,000 . \$ 65$

MP 87. Survey of geology and geologic materials, and geologic hazards in proposed access corridors in the Lookout Ridge Quadrangle, Alaska, by D.S.P. Stevens and R.L. Smith, 5 sheets, scale 1:250,000. $\$ 65$

MP 88. Survey of geology and geologic materials, and geologic hazards in proposed access corridors in the McGrath Quadrangle, Alaska, by R.D. Reger, D.S.P. Stevens, and R.L. Smith, 5 sheets, scale $1: 250,000 . \$ 65$.

MP 89. Survey of geology and geologic materials, and geologic hazards in proposed access corridors in the Meade River Quadrangle, Alaska, by R.D. Reger, D.S.P. Stevens, N.D. Bowman, K.M. Campbell, and R.L. Smith, 5 sheets, scale 1:250,000. \$65.

MP 91. Survey of geology and geologic materials, and geologic hazards in proposed access corridors in the Melozitna Quadrangle, Alaska, by R.D. Reger, D.S.P. Stevens, and R.L. Smith, 5 sheets, scale $1: 250,000 . \$ 65$.

MP 94. Survey of geology and geologic materials, and geologic hazards in proposed access corridors in the Mount McKinley Quadrangle, Alaska, by R.D. Reger, D.S.P. Stevens, and R.L. Smith, 5 sheets, scale 1:250,000. $\$ 65$.

MP 97. Survey of geology and geologic materials, and geologic hazards in proposed access corridors in the Noatak Quadrangle, Alaska, by D.S.P. Stevens, K.M. Campbell, and R.L. Smith, 4 sheets, scale 1:250,000. $\$ 52$.

MP 127. Alaska coalbed and shallow gas resources, May 2001 Workshop Proceedings, edited by C.E. Barker. J.G. Clough, and T.A. Dallegge, 2003, 1 CD-ROM. \$10.

MP 131. Bibliography of information on Alaska volcanoes, by C.E. Cameron, J.H. Triplehorn, and C.L. Robar, 2003, 1 CD-ROM. \$10.

MP 128. 2001 Guide to the Petroleum Geology and Shallow Gas Potential of the Kenai Peninsula, Alaska: A Field Trip Guidebook, by T.A. Dallegge, 2003, 1 CD-ROM. \$10.

\section{PRELIMINARY INTERPRETIVE REPORT}

PIR 2003-1. Alluvial facies and paleosols in the Cretaceous Nanushuk formation, Kanayut River, North Slope, Alaska, Preliminary results from the 2001 field season, by P.J. McCarthy, 19 p. \$2.

\section{PROFESSIONAL REPORTS}

PR 120. Short notes on Alaska geology 2003, by K.H. Clautice and P.K. Davis, eds., 2003, 117 p. \$17.

a. Potassic magmatism on St. Lawrence Island, Alaska, and Cape Dezhnev, northeastern Russia: Geochemistry, 40Ar/39Ar ages, and implications for the tectonic evolution of the Bering Strait region, by J.M. Amato, E.L. Miller, A.T. Calvert, Jaime Toro, and J.E. Wright, 20 p.

b. Ore mineralogy and mineral compositions from the Golden Zone Mine, southcentral Alaska, by B.G. Gage and R.J. Newberry, 13 
p.

c. Stratigraphy and geochemistry of the RW Zone, a new discovery at the Glacier Creek VMS prospect, Palmer property, Porcupine mining district, southeastern Alaska, by D.W. Green, J.G. MacVeigh, Merrill Palmer, D.H. Watkinson, and M.J. Orchard, 17 p.

d. A Permian cool-water limestone from the Chulitna terrane, southcentral Alaska, by Simone Montayne and M.T. Whalen, 10 p.

e. Mineralization and structural controls in the Kensington Mine and Berners Bay area, southeastern Alaska, by Earl Redman, Stan Caddey, Dave Harvey, and Mike Jaworski, 7 p.

f. Preliminary petrographic study of 11 Mississippian to Tertiary age sandstones, Sagavanirktok Quadrangle, Brooks Range foothills and North Slope, Alaska, by R.R. Reifenstuhl and A.E. Reifenstuhl, 11 p.

g. Gastropod opercula from the Silurian and Devonian of Alaska, by D.M. Rohr and R.B. Blodgett, 3 p.

h. New Silurian Murchisoniid gastropods from Alaska and a review of the genus Coelocaulus, by D.M. Rohr, R.B. Blodgett, and Jirí Frýda, 7 p.

i. Alaskadiscus, A new Bellerophontoidean gastropod from the upper Ordovician of the York and Farewell terranes of Alaska, by D.M.

Rohr, Jirí Frýda, and R.B. Blodgett, 5 p.

j. New mapping near Iron Creek, Talkeetna Mountains, indicates presence of Nikolai Greenstone, by J.M. Schmidt, M.B. Werdon, and Bruce Wardlaw, 8 p.

k. New paleontological investigations of Triassic carbonate rocks in the Upper Chulitna District (Chulitna terrane), southcentral Alaska, by G.D. Stanley and J.M. Yarnell, 8 p.

PR 122. Bedrock geologic map of the Delta mineral belt, Tok mining district, Alaska, by S.S. Dashevsky, C.F. Schaefer, and E.N. Hunter, 2003, 122 p., 2 sheets, scale 1:63,360. \$16.

\section{RAW DATA FILE}

RDF 2003-1. Coal analyses (proximate and ultimate) from the Delta Junction area, Alaska, by R.L. Stull and Paige Peapples, 2003, 13 p. $\$ 2$.

RDF 2003-2. Major-oxide, minor-oxide, trace-element, and geochemical data from rocks collected in the Big Delta Quarangle, Alaska in 2002, by M.B. Werdon, .R.J. Newberry, J.E. Athey, D.J. Szumigala, L.K. Freeman, P.J. Wilson, R.R. Lessard, K.R. Hendry, and M.A. Wiltse, 2003, 45 p. $\$ 5$.

RDF 2004-1. 40AR/39AR ages of rocks collected in the Livengood C3, C-4, and B-4 Quadrangles, Alaska, by J.E. Athey, P.W. Layer, and Jeff Drake, 2004, 12 p. \$2.

RDF 2004-2. Major-oxide, minor-oxide, and trace-element geochemical data from rocks collected in the Livengood Quadrangle, Alaska in 2001 and 2003, by J.E. Athey, M.B. Werdon, D.J. Szumigala, R.J. Newberry, S.A. Hicks, and H.A. Erickson, 2004, 14 p., 1 sheet, scale $1: 63,360 . \$ 15$.

\section{REPORTS OF INVESTIGATIONS}

RI 2002-4. Preliminary volcano-hazard assessment for Shishaldin Volcano, Alaska, by J.E. Begét, C.J. Nye, J.R. Schaefer, and P.L. Stelling, 2003, 28 p., 1 sheet, scale 1:500,000. \$16.

\section{SPECIAL REPORTS}

SR 57. Alaska's mineral industry 2002, by D.J. Szumigala, R.C. Swainbank, M.W. Henning, and F.M. Pillifant, 2003, 63 p. Free.

\section{WHERE TO ORDER}

ORDERING INFORMATION
For each publication ordered, include both the publication title and number. Mail orders are payable in advance. Make check or money order in U.S. currency and payable to the State of Alaska. Credit cards are accepted. Telephone orders are accepted by the Fairbanks office between 8 a.m. and 5 p.m. Alaska time. Fax and email requests are accepted any time; these orders will be invoiced. If you would like to leave your order on voice mail, this can also be done 24 hours a day and you will be invoiced.

\section{SHIPPING \& HANDLING}

-Domestic postage - \$1.00/copy of each report

- Canada and Mexico - \$1.50/copy of each report

-All other international - \$2.50 surface

$\$ 5.00$ air/copy of each report

-For rolled-map orders requiring mailing tubes, include an additional $\$ 3.50$.
Publications of the Division of Geological \& Geophysical Surveys are available over the counter, by mail, phone, fax, or email from the DGGS Fairbanks office:

ATTN: Geologic Communications Section-Publication Sales

Alaska Division of Geological \& Geophysical Surveys, 3354 College Rd.

Fairbanks, AK 99709-3703

(907) 451-5020 Fax (907) 451-5050

Email: dggspubs@dnr.state.ak.us

Prices of DGGS publications are subject to change. Increases in costs make it necessary to raise the selling prices of many publications offered. It is not feasible for DGGS to change the prices stated in previous announcements and publications in stock, so the prices charged may differ from the prices in the announcements and publications. Overpayments of $\$ 2$ or less will not be refunded.

\begin{tabular}{|c|}
\hline Please send address corrections to: \\
Newsletter, Alaska Division of Geological \& Geophysical Surveys \\
3354 College Road, Fairbanks, AK 99709-3707 \\
(907) 451-5020 (907)451-5050 fax \\
email: dggsnews@dnr.state.ak.us \\
http://wwwdggs.dnr.state.ak.us \\
\hline
\end{tabular}

\section{Visit our web page at http://www.dggs.dnr.state.ak.us}

